\title{
SPECC1 Gene
}

National Cancer Institute

\section{Source}

National Cancer Institute. SPECC1 Gene. NCI Thesaurus. Code C97531.

This gene may be involved in nuclear structure. 